\title{
Nectar secretion dynamics of Hungarian local pear cultivars
}

\author{
Á. Farkas and Zs. Orosz-Kovács \\ University of Pécs, Department of Botany, Pécs, Hungary \\ Received August 27, 2002; accepted January 7, 2003 \\ Published online: June 2, 2003 \\ (c) Springer-Verlag 2003
}

\begin{abstract}
The dynamics of daily nectar secretion was studied in 28 local pear cultivars in a Hungarian cultivar collection and three main types were distinguished. 1. Cultivars secreting nectar continuously are the most favourable for pollinators, rewarding them both with nectar and pollen. 2 . Cultivars with discontinuous nectar secretion have sufficient insect attraction only if anther dehiscence is continuous during the day. In the first two types nectar secretion peaks usually appeared at 9:00 or $10: 00,14: 00$ or $15: 00$ and $18: 00$ or 19:00, with 4-5hour intervals. 3. In some cultivars no nectar secretion was observed in any or some of the studied years, these being the least attractive for pollinators. The cultivars studied did not necessarily show the same type of nectar secretion dynamics in each season. From the viewpoint of pollination it is also of high importance, in which developmental phase nectar secretion begins.
\end{abstract}

Key words: Insect attraction, local cultivars, nectar secretion dynamics, pear, Pyrus communis L.

For pollinators the most important primary attractants are pollen and nectar. The process of nectar production is governed by numerous endogenous and environmental factors (Walker et al. 1974, Cruden and Herman 1983). Some researchers (Pesti 1976, Orosz-Kovács 1992) have proposed that periodicity in nectar production is endogenous, as described in several plant taxa. Changes in nectar production and composition during the day in the families Boraginaceae and Brassicaceae were characterised by Corbet (1978). Mačukanović and Blazenčić (1998) studied the diurnal and seasonal dynamics of nectar secretion in the Lamiaceae family. Witt et al. (1999) stated that in two genera of Caryophyllaceae the dynamics of nectar secretion differed from species to species, and also within species.

Nectar secretion dynamics of the Rosaceae family has been investigated by a number of researchers. Studying several taxa belonging to the subfamily Prunoideae, Orosz-Kovács (1991, 1992) and Orosz-Kovács et al. (1989, 1992, 1995) stated that homogamous flowers secreted nectar at $6 \mathrm{~h}$ intervals, whereas dichogamous cultivars secreted nectar at 12 hour intervals. In the subfamily Maloideae nectar production maxima could be detected every 4 hour in apple cultivars (Scheid-Nagy Tóth 1991, 2000; OroszKovács et al. 1994; Szabó-Mühlenkampf 1994). According to nectar production studies on Crataegus species (also belonging to Maloideae), the concentration of nectar shows a strong correlation with ambient relative humidity, but microclimatic factors within and around the flower, as well as chemical effects may also have an important role (Corbet et al. 1979). In this genus nectar production peaks appeared in the morning, around midday and in the evening, 
Á. Farkas and Zs. Orosz-Kovács: Nectar secretion dynamics of pear cultivars
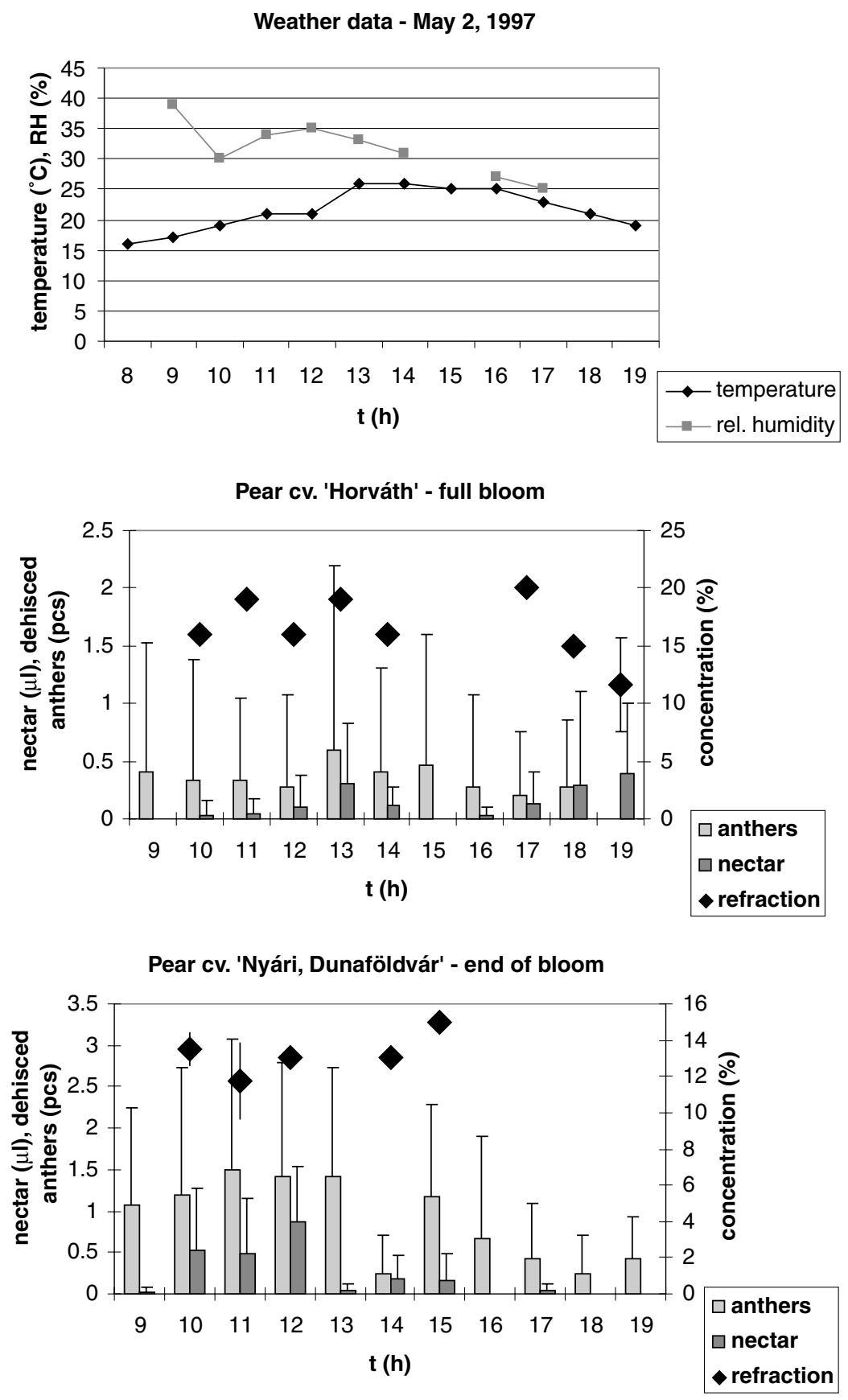

Fig. 1. Hourly mean nectar production and anther dehiscence in flowers of pear cultivars, Újfehértó, May 2, 1997

when secretion outweighed loss by reabsorption or insect visits.

Pear nectaries are automorphic and receptaculo-ovarial, situated on the adaxial side of the hypanthium and the apical part of the ovary (Fahn 1953, Frei 1955, Szilva 1969, Farkas and Orosz-Kovács 2001). In pear flowers the most abundant nectar production can be observed in the morning hours, coinciding with the lowest sugar content of the secretory product (Nyárády 1958, Simidchiev 1970).

Since pear cultivars are mainly autosterile and entomogamous, investigating floral rewards is essential. The dynamics of nectar secretion (time and duration of secretory activity, volume and concentration of nectar), as well as 


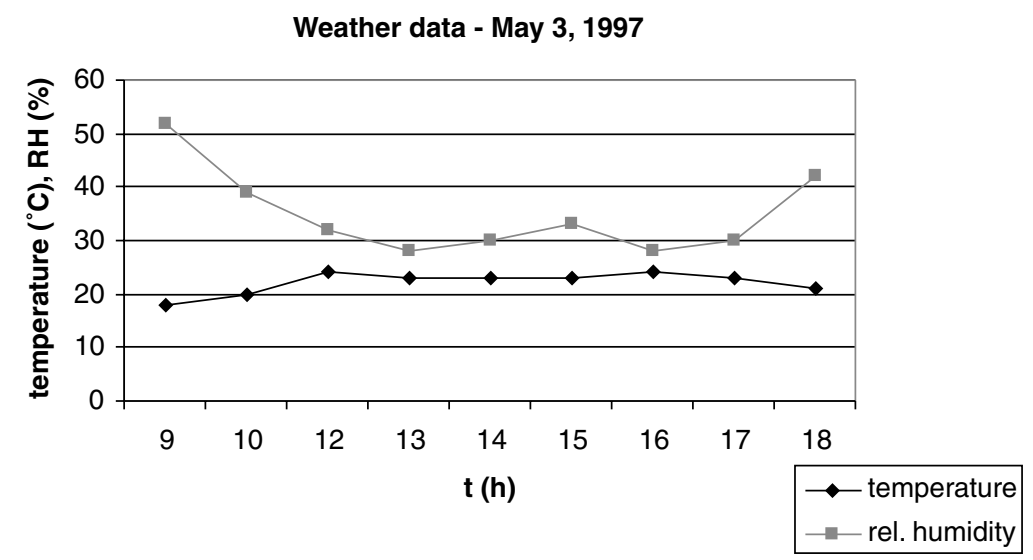

Pear cv. 'Clapp' - full bloom

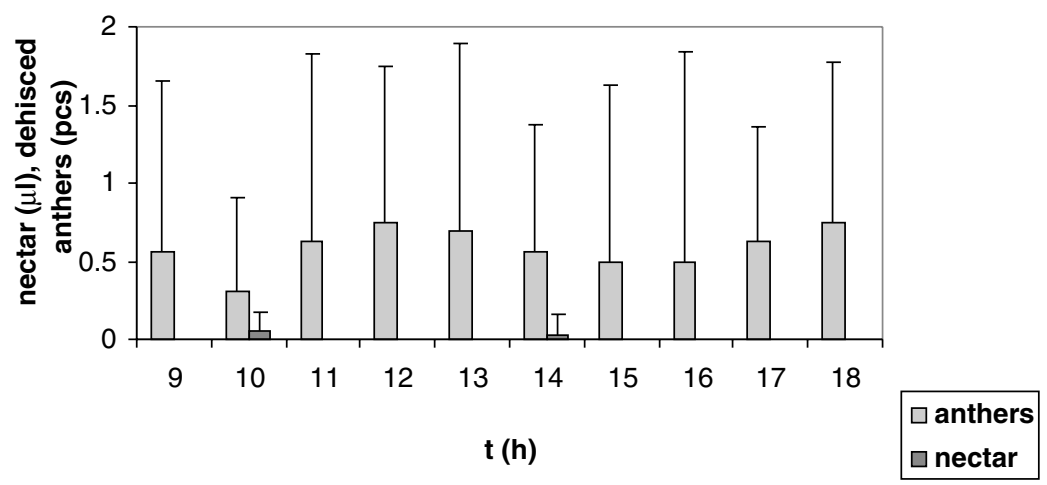

Pear cv. 'Viki' - full bloom

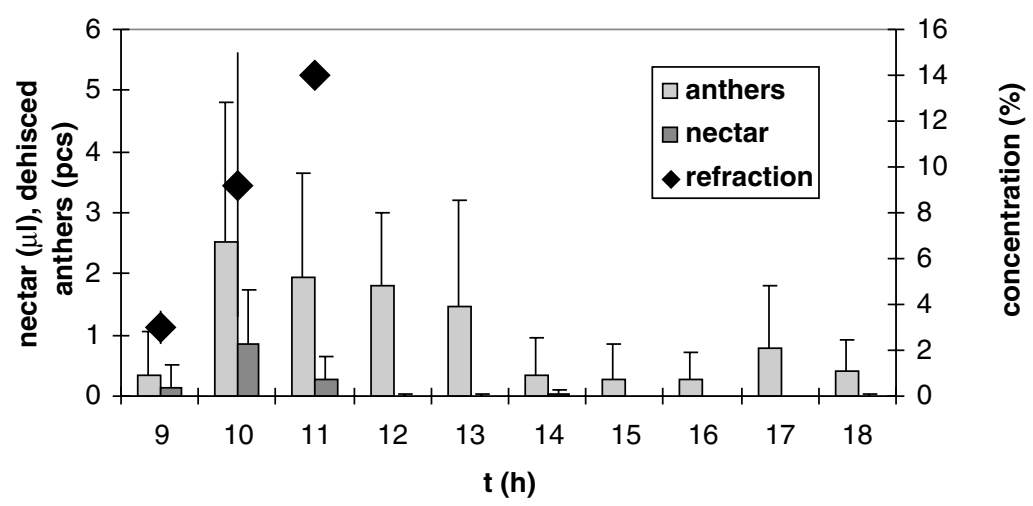

Fig. 2. Hourly mean nectar production and anther dehiscence in flowers of pear cultivars, Újfehértó, May 3, 1997

that of pollen shedding has to be studied carefully in order to be able to correlate these patterns with pollination requirements in pear orchards.

Variability in the dynamics of nectar secretion can be interesting also from the point of view of systematics. Investigating patterns of nectar secretion may help to clarify the genetic relationships and the origin of local cultivars.

\section{Materials and methods}

Nectar secretion dynamics was studied in 28 pear cultivars in the pear genebank of the Research and Extension Centre for Fruitgrowing, Újfehértó, Hungary. The genebank contains mainly Hungarian local pear cultivars, each represented by two specimens. Nectar was extracted hourly out of 15-20 numbered flowers from one or two trees 
Weather data - April 23, 1998

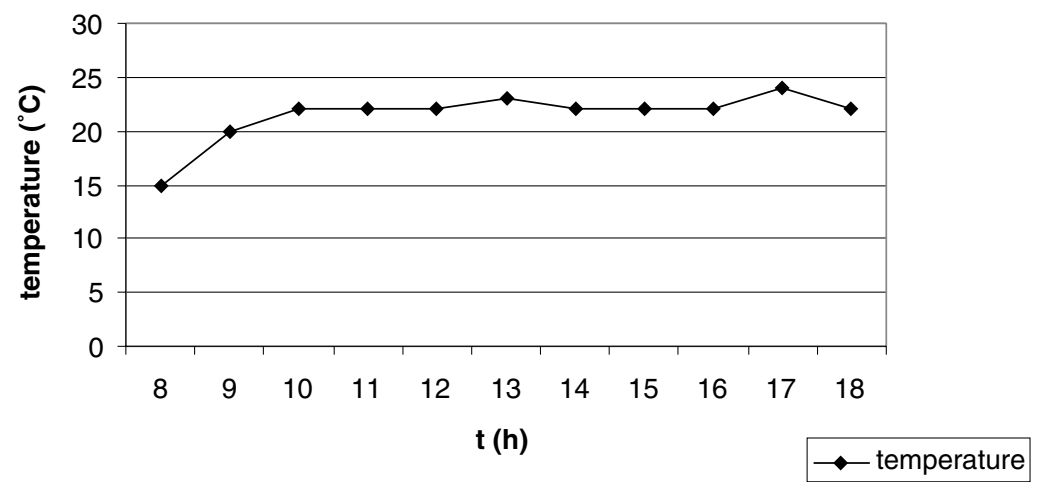

Pear cv. 'Clapp' - end of bloom

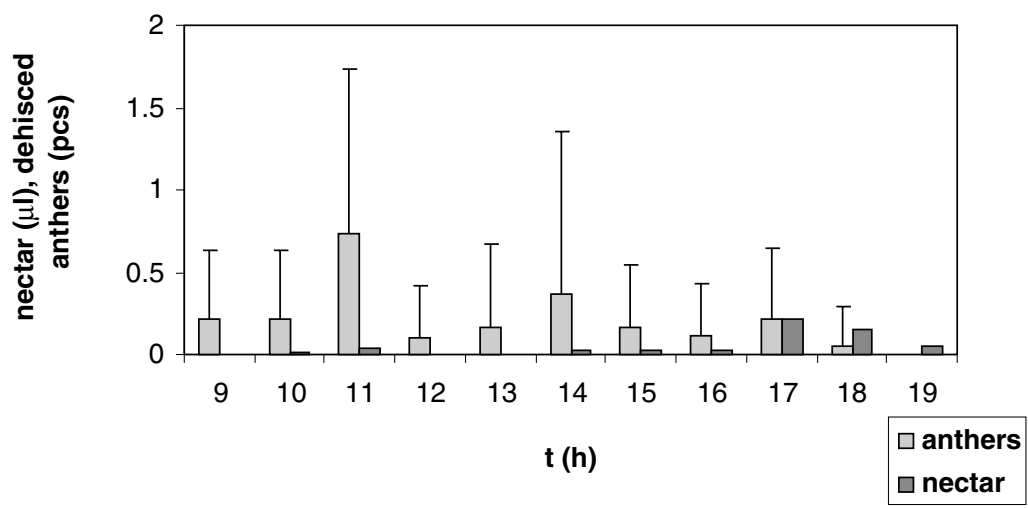

Fig. 3. Hourly mean nectar production and anther dehiscence in flowers of pear cultivars, Újfehértó, April 23, 1998 per cultivar. Among the flowers there were buds, buds in the balloon stage (just before opening), freshly opened flowers and flowers with some anthers already dehisced. The amount of the secretory product was determined by calibrated microcapillaries, nectar concentration was measured by a pocket refractometer (type OG-101/A, measuring in the range $0-85 \%$ ). When calculating means, data of all flowers studied were taken into consideration (even those not having secreted any nectar in the given hour), in order to gain a general picture about nectar secretion patterns of the tree. Besides nectar volume and concentration the following parameters were recorded: time of sampling, air temperature $\left({ }^{\circ} \mathrm{C}\right)$, relative air humidity $(\%)$, flowering stage, flower age (number of dehisced anthers, state of stigma) and the presence or absence of bees. Air temperature was measured by a thermometer hung up on the tree at the level of the flowers studied, relative air humidity was measured by a pocket psychrometer (type 'Hygrocheck'). The flowers studied were covered by plain tulle net to prevent visits of pollinator insects.
Detailed apicultural observations were not carried out, however it was recorded if on the whole bees visited the flowers of a tree or not.

From the 28 cultivars studied the following ones have been selected in this paper to represent the main types of nectar secretion dynamics:

\begin{tabular}{lll}
\hline Cultivar & $\begin{array}{l}\text { Year of } \\
\text { study }\end{array}$ & $\begin{array}{l}\text { Flowering } \\
\text { stage }\end{array}$ \\
\hline $\begin{array}{l}\text { Bajai 6 } \\
\text { Bőtermó Nyári } \\
\text { Kálmán }\end{array}$ & 2000 & $\begin{array}{l}\text { End of bloom } \\
\text { End of bloom }\end{array}$ \\
Clapp & 2000 & \\
& 1997,1999 & Full bloom \\
Horváth & 1998 & End of bloom \\
Jó szürke & 1997 & Full bloom \\
Mosoly & 1998 & Full bloom \\
Nagyasszony & 1999,2000 & Full bloom \\
Nyári, Dunaföldvár & 2000 & End of bloom \\
Viki & 1997 & End of bloom \\
& 1997 & Full bloom \\
& 2000 & End of bloom \\
\hline
\end{tabular}



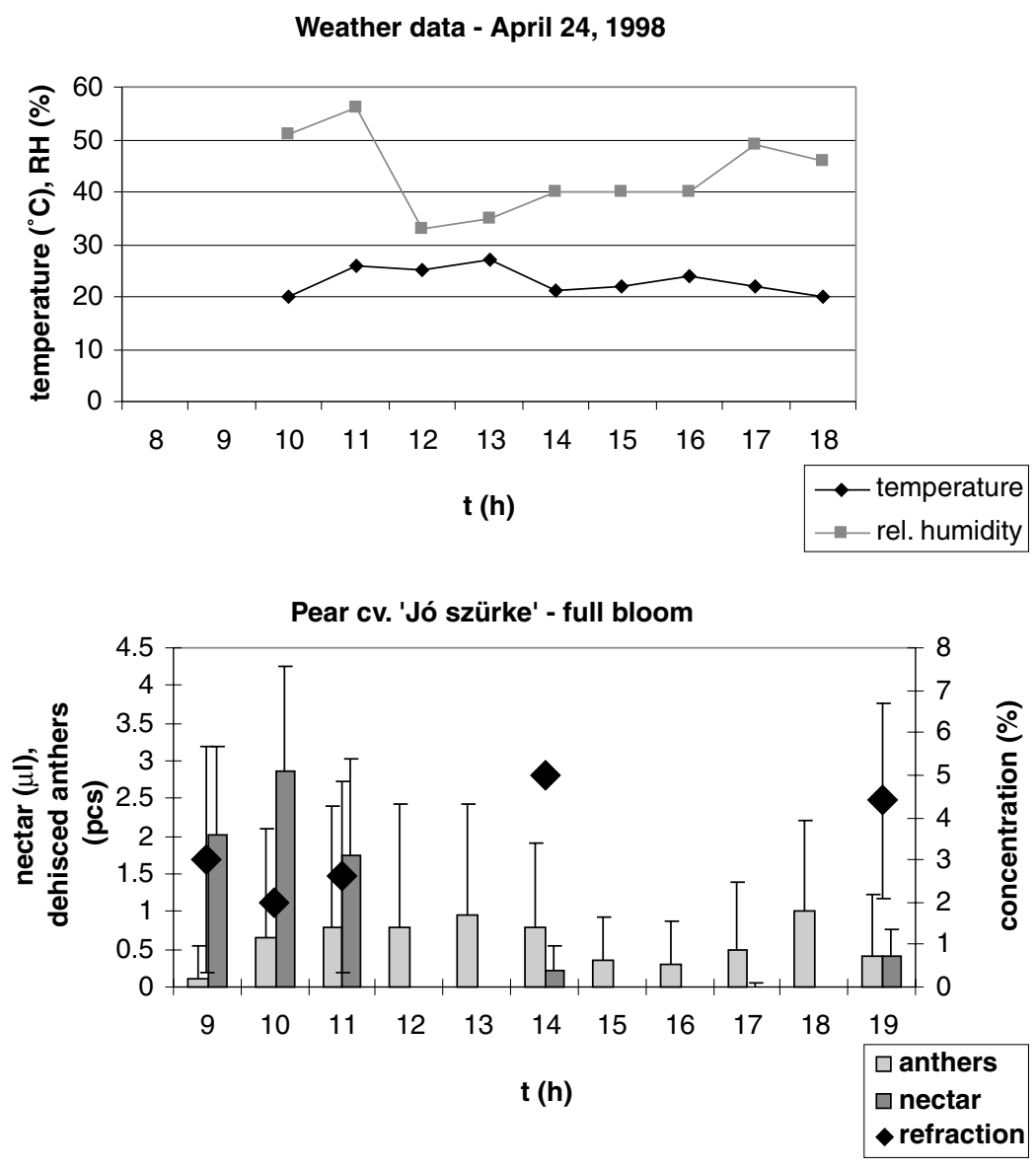

Fig. 4. Hourly mean nectar production and anther dehiscence in flowers of pear cultivars, Újfehértó, April 24, 1998

\section{Results}

On the basis of daily nectar secretion dynamics, the studied pear cultivars could be classified into three categories.

1. Some cultivars did not secrete any nectar in the years of study, as for example cv. 'Mosoly' in 1999 and 2000 (Fig. 8). The flowers of other cultivars yielded a minimal amount of secretory product only in some years (e.g. 'Clapp' - Figs. 2, 3, 5).

2. The cultivars in the second group secreted nectar continuously from morning to evening or at least for most of the day, like 'Nyári, Dunaföldvár' (Fig. 1) and 'Horváth' (Fig. 1). In some of these cultivars nectar production peaks appeared more or less regularly, with 4-5 hour intervals.

3. The majority of the cultivars could be characterised by a discontinuous nectar secretion, as for example 'Nagyasszony' (Fig. 7) and 'Bötermő Nyári Kálmán' (Fig. 6), where the secretory phase was followed by a shorter or longer break.

In most cultivars belonging to the last category nectar production could be observed at 9:00 or $10: 00$, then at $14: 00$ or $15: 00$, and finally at 18:00 or 19:00, again with 4-5-hour intervals, like in the case of 'Bajai 6' in 2000 (Fig. 6) and 'Jó szürke' in 1998 (Fig. 4) and 2000.

In some cultivars the early afternoon secretory activity was missing, probably due to the high temperatures measured in this period (e.g. 'Nagyasszony' - Fig. 7), whereas in others the evening nectar production peak could not be observed (e.g. 'Nyári, Dunaföldvár' - Fig. 1). Some taxa produced nectar only in the early and late morning, then 

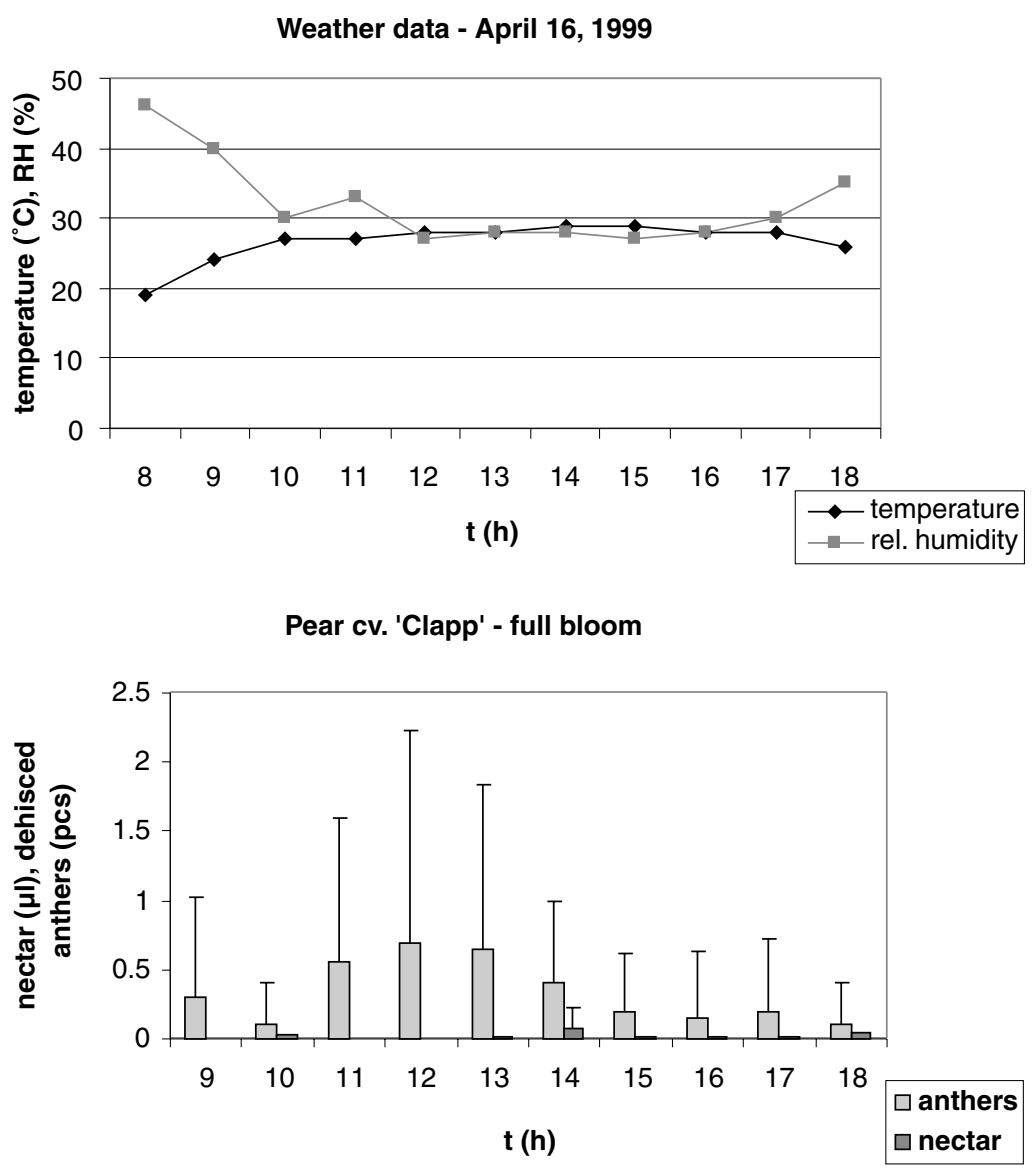

Fig. 5. Hourly mean nectar production and anther dehiscence in flowers of pear cultivars, Újfehértó, April 16, 1999

secretion ceased for the rest of the day, like in cv. 'Viki' (Figs. 2, 7).

The cultivars did not necessarily belong to the same type of nectar secretion dynamics in each year, in some cases they could be included in various categories depending on the season, weather and flowering stage (e.g. 'Clapp' Figs. 2, 3, 5).

From the viewpoint of nectar secretion the sunny, but not too hot $\left(20-27^{\circ} \mathrm{C}\right)$ and windless weather proved to be favourable, with a relatively high air humidity $(30-40 \%)$. In accordance with the highest temperatures, pollen shedding in most cases was most intensive in the early afternoon, although in a few cultivars most anthers opened in the late morning hours.

\section{Discussion}

From the point of view of insect attraction and pollination it is advantageous if a cultivar offers both nectar and pollen to pollinating insects in the period of stigma activity. The most favourable situation is when a cultivar produces a high amount of nectar without disruption, besides offering abundant pollen, i.e. ensuring insect attraction during the whole day. At the same time the quantity and concentration of the secretory product should also be attractive enough for bees, since in this period other pollinators are not too frequent in the orchard, due to the relatively early flowering date and usually cool weather. Taking into consideration all the above aspects, only a few cultivars were highly attractive for honeybees: 'Csákvári téli', 'Horváth' and 'Nyári, Dunaföldvár'.

Cultivars with discontinuous nectar secretion have sufficient insect attraction only if anther dehiscence is continuous during the day, ensuring the presence of at least one primary attractant. This could be observed in 
Weather data - April 20, 2000

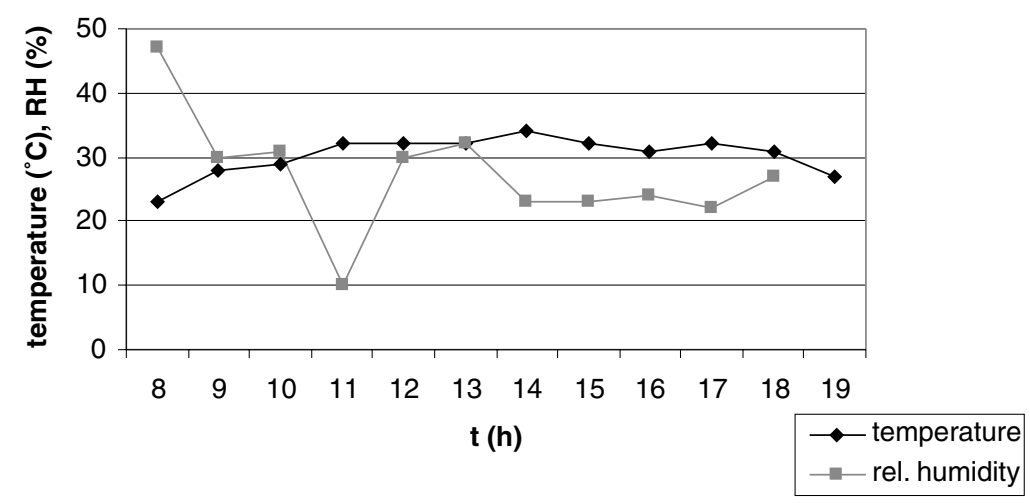

Pear cv. 'Bajai 6' - end of bloom
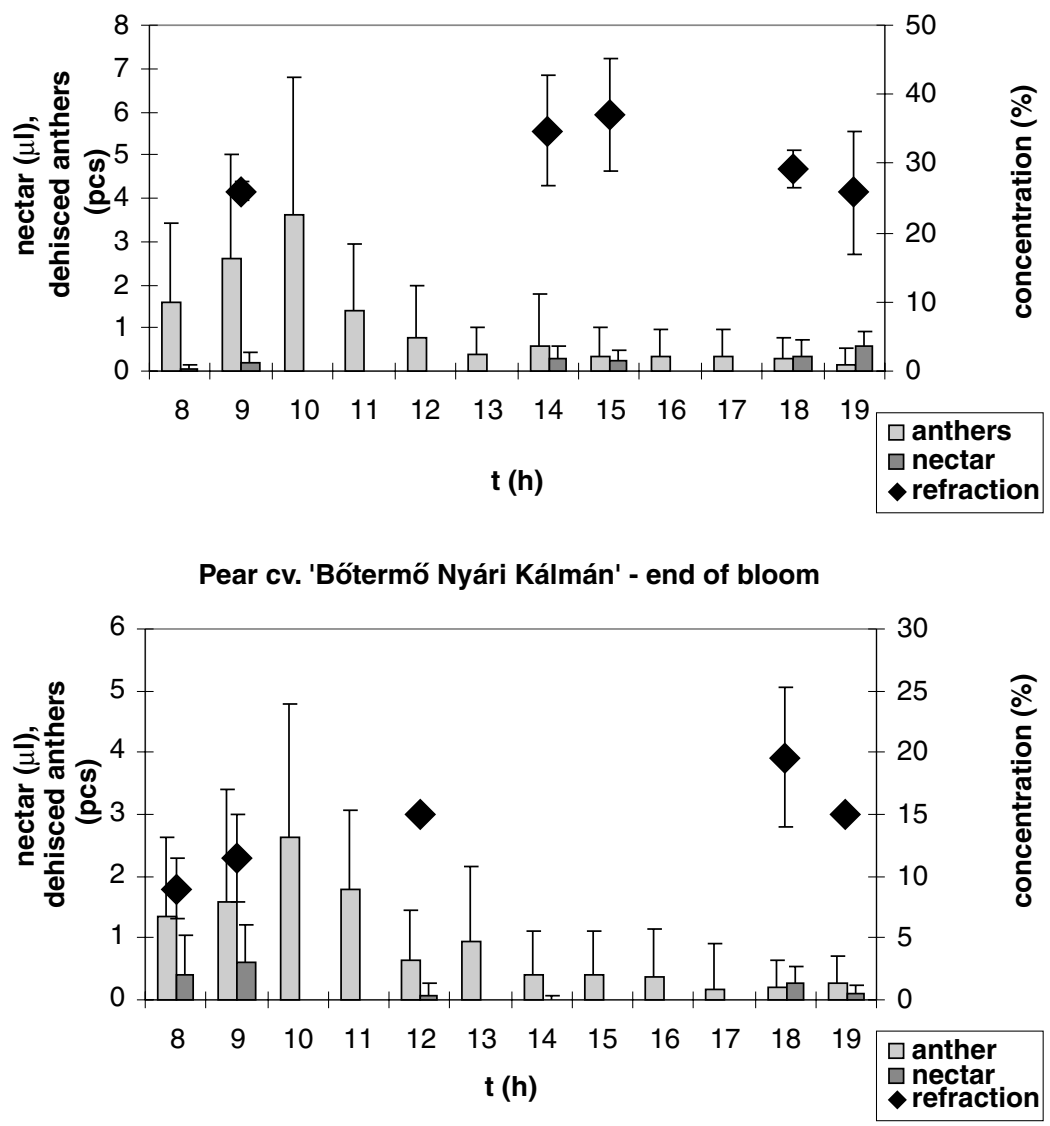

Fig. 6. Hourly mean nectar production and anther dehiscence in flowers of pear cultivars, Újfehértó, April 20, 2000

cvs. 'Bőtermő Nyári Kálmán', 'Jó szürke', 'Nagyasszony', 'Nyárig tartó 6/19', 'Solymári cukor' and 'Viki'.

The least advantageous situation could be observed in cultivars which did not secrete any nectar, because here pollen was the only reward available for pollinators. If these cultivars offer pollen abundantly, and anthers dehisce continuously with great intensity, they may still be attractive for honeybees, and pollination can take place. Such was the case in cv. 'Mosoly' in both years of study (Fig. 8), 

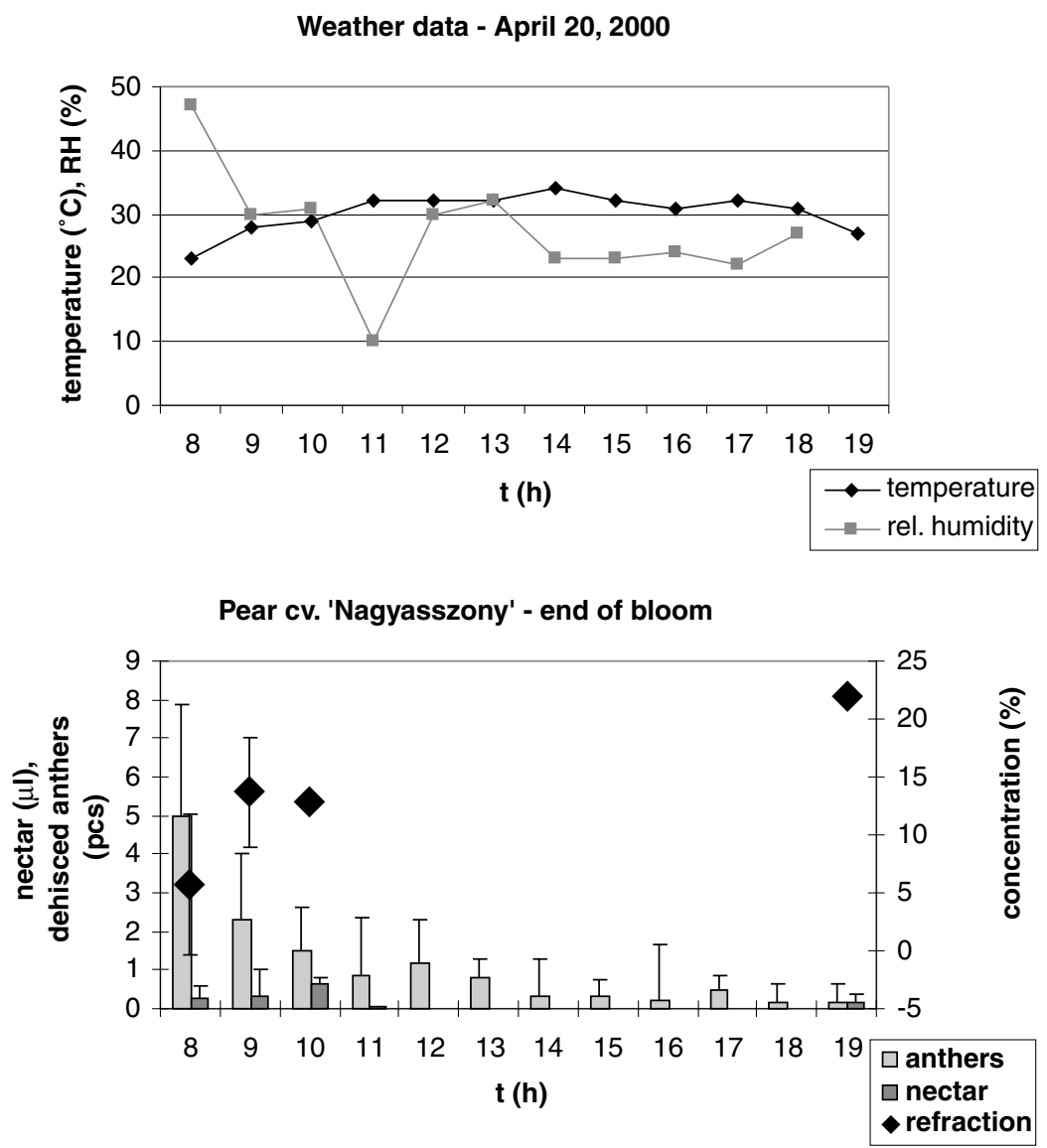

Pear cv. 'Viki' - end of bloom

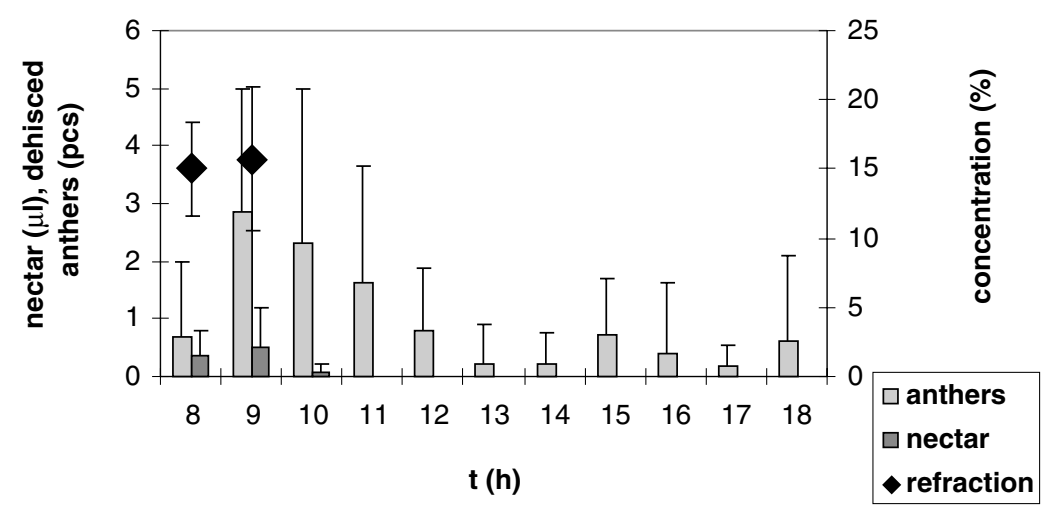

Fig. 7. Hourly mean nectar production and anther dehiscence in flowers of pear cultivars, Újfehértó, April 20, 2000

where flower-visiting honeybees were observed in great numbers on the whole tree. In some taxa the nectar produced could not be measured by microcapillaries, however, the glistening of the nectary surface showed a slight secretory activity of the gland, which can be also satisfactory from the viewpoint of insect attraction. For example cv. 'Viki' produced a measurable amount of nectar only in the morning hours (Figs. 2, 7), but was visited by a high number of bees during the whole day.

The commencement of nectar secretion is also of great importance, especially in protogynous flowers, which frequently occur in pear cultivars (Péter 1975, Terpó 1980, Nyéki 1980, Davary-Nejad 1997). In certain cultivars (e.g. 
Weather data - April 21, 2000

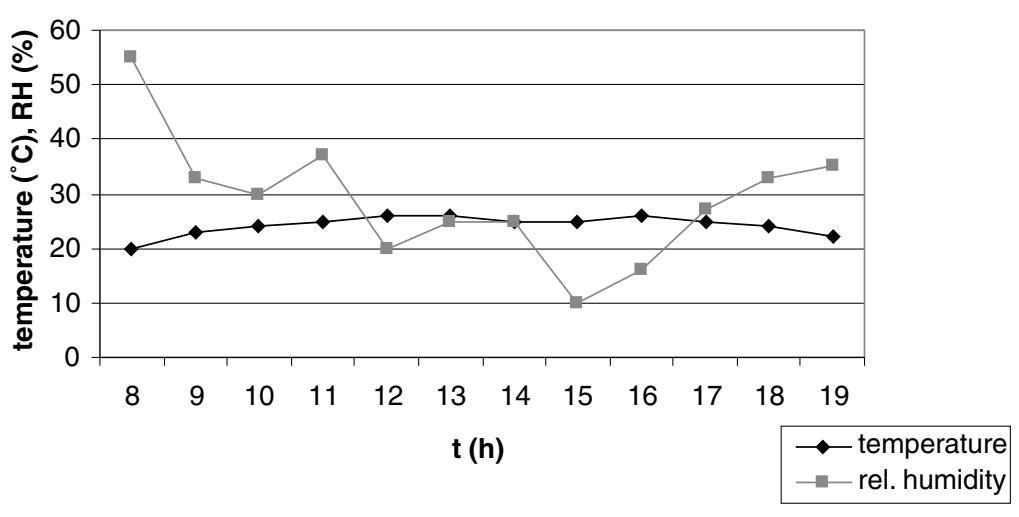

Pear cv. 'Mosoly'- full bloom

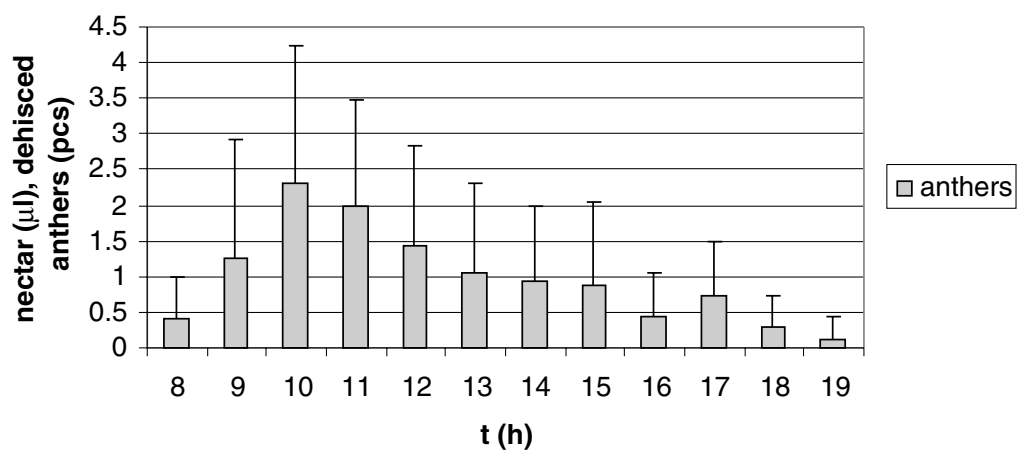

Fig. 8. Hourly mean nectar production and anther dehiscence in flowers of pear cultivars, Újfehértó, April 21, 2000
'Miklós') the secretory product is already present in the balloon stage (just before flower-opening) and later in the opened flower, thus insect attraction is already ensured in the protogynous phase. In protogynous cultivars where nectar secretion starts only in the opened flower, pollination can only take place by wind or small sized beetles in the balloon stage (e.g. cvs. 'Dániel', 'Horváth'). Only wind pollination can be expected in cultivars whose flowers do not secrete any nectar in the protogynous phase, preceding the pollen-shedding stage (e.g. cv. 'Aratási cukor'). At the time of anther dehiscence, when bees appear, the stigma has already lost its receptivity and consequently bee-pollination cannot take place.

In the case of delayed homogamy - described earlier in sour cherry and apple cultivars (Orosz-Kovács 1991, Scheid-Nagy Tóth 1991), but also observed in some pear cultivars - flowers function first as protogynous, but the stigma remains receptive also during pollenshedding. As in protogynous cultivars, nectar secretion may start in the balloon stage (e.g. cv. 'Clapp') or only in the open flower (e.g. cvs. 'Bőtermő Nyári Kálmán' and 'P3 Pettend'), whereas in some cultivars (e.g. 'Jég') no nectar production was observed.

In homogamous flowers stigma receptivity and pollen-shedding are simultaneous. Also in this floral type certain cultivars (e.g. 'Bajai 6', 'Viki') secrete nectar in the balloon stage and afterwards in the young open flower. In others (e.g. cv. 'Cinderi') secretion begins only in the opened flower, but preceding anther dehiscence. Nectar secretion can often be detected only in pollen-shedding flowers (e.g. cv. 'Clapp'). The secretory product becomes available for pollinators after the filaments, originally curled down the stigma, have leaned away from it. Among cultivars with homogamous flowers no nectar secretion 
was observed in cvs. 'Ötvös' and 'Zánkai magonc'.

In the Rosaceae family nectar production peaks can frequently be observed in the early morning, as for example in Prunus spinosa and P. mahaleb (Guitian et al. 1993) from the subfamily Prunoideae, and also in Crataegus, Malus and Pyrus species from the Maloideae (Nyárády 1958; Simidchiev 1970; Corbet et al. 1979; Orosz-Kovács et al. 1990, 1994). Similarly, in some Hungarian local pear cultivars the most abundant nectar production could be measured in the morning hours (e.g. cv. 'Viki'), however, other types of secretion dynamics could also be observed.

Similarly to apple cultivars and Crataegus species, nectar secretory peaks with 4-5-hour intervals could often be observed in pear cultivars (Corbet et al. 1979; Orosz-Kovács et al. 1990, 1994; Scheid-Nagy Tóth 1991, 2000; Szabó-Mühlenkampf 1994). In the case of pear, however, the secretory rhythm was not as regular as in apple, where production maxima appeared every 4 hour.

\section{References}

Corbet S. A. (1978) Bee visits and the nectar of Echium vulgare L. and Sinapis alba L. Ecological Entomology 3: 25-37.

Corbet S. A., Unwin D. M., Prys-Jones O. E. (1979) Humidity, nectar and insect visits to flowers, with special reference to Crataegus, Tilia and Echium. Ecological Entomology 4: 9-22.

Cruden R. W., Hermann S. M. (1983) Studying Nectar? Some observations on the art. In: Bentley B., Elias T. (eds.) The Biology of Nectaries. Columbia Univeristy Press, New York, pp. 223-242.

Davary-Nejad G. H. (1997) Microphenology of flowers of pear cultivars. Acta Hort. 441: 299305.

Fahn A. (1953) The topography of the nectary in the flower and its phylogenetical trend. Phytomorphology 3: 424-426.

Farkas Á., Orosz-Kovács Zs. (2001) Körtefajták nektáriumának hisztológiai jellemzése. (Histological description of the nectary in pear cultivars) XI. Magyar Növényanatómiai Szimpózium, Keszthely, 2001. aug. 23-25., pp. 32-33.

Frei E. (1955) Die Innervierung der floralen Nektarien dikotyler Pflanzenfamilien. Diss. E. T. H. Zürich; Ber. Schweiz. Bot. Ges. 65: 60.

Guitian J., Guitian P., Sanchez J. M. (1993) Reproductive biology of two Prunus species (Rosaceae) in the Northwest Iberian peninsula. Plant Syst. Evol. 185: 153-165.

Mačukanović M., Blazenčić Z. (1998) Diurnal and seasonal dynamics of nectar secretion of some species in the family Lamiaceae. Acta Veterinaria (Beograd) 48: 173-184.

Nyárády A. (1958) A méhlegelő és növényei. (Bee pasture and its plants.) Mezőgazd. és Erdészeti Állami Könyvkiadó, Bukarest.

Nyéki J. (1980) A körte. (Pear) In: Nyéki J. (szerk.) Gyümölcsfajták virágzásbiológiája és termékenyülése. (Floral biology and fertilisation of fruit cultivars). Mg. Kiadó, Budapest, pp. 168-184.

Orosz-Kovács Zs. (1991) A cseresznye és a meggy nektáriumstruktúrája és nektárprodukciója. (Nectary structure and nectar production in sweet and sour cherry.) doctoral dissertation, Pécs, JPTE Dept. of Botany, pp. 112.

Orosz-Kovács Zs. (1992) A florális szekréció endogén ritmusának funkciója a cseresznyefajták megporzásásban. (Significance of endogenous nectar secretory rhythm in pollination of cherry cultivars.) Kertgazdaság 4: 47-54.

Orosz-Kovács Zs., Gulyás S., Halászi Zs. (1989) Periodicity of nectar production of sour cherry cv. Pándy. Acta Bot. Hung. 35: 237-244.

Orosz-Kovács Zs., Nagy Tóth E., Csatos A., Szabó A. (1990) A nektáriumszerkezet és a nektárprodukció összefügése néhány almafajtánál. (Relationship between nectary structure and nectar production in some apple cultivars.) Bot. Közl. 77: 127-132.

Orosz-Kovács Zs., Gulyás S., Kaposvári F. (1992) Pollination biology of sour cherry varieties of protogyn blossoming. Acta Biol. Szeged. 38: 4755.

Orosz-Kovács Zs., Nagy Tóth E., Mühlenkampf E. (1994) The effect of microclimatic factors on the attractivity of apple cultivars. XXIst Congress of the Hung. Biol. Soc., Pécs, 1994.

Orosz-Kovács Zs., Nyujtó F., Kerek M. M. (1995) The role of floral nectar production in fertility of apricots. Acta Horticulturae 384: 361-366. 
Pesti J. (1976) Daily fluctuations in the sugar content of secretion in the Compositae. Acta Agr. Ac. Sci. Hung. 25: 5-17.

Péter J. (1975) Gyümölcstermő fák és cserjék. Körte. (Fruit trees and shrubs. Pear.) In: Halmágyi L. és Keresztesi B. (szerk.): A méhlegelő. (Bee pasture) Akadémiai Kiadó, Budapest.

Scheid-Nagy Tóth E. (1991) Almafajták nektáriumszerkezete és nektárprodukciója. (Nectary structure and nectar production in apple cultivars.) Doct. dissertation. JPTE, Dept. of Botany, pp. 160.

Scheid-Nagy Tóth E. (2000) Az alanyok hatása az almafajták primer florális attraktivitására. (Effect of rootstocks on primary floral attractivity in apple cultivars.) $\mathrm{PhD}$ dissertation. Univ. of Pécs, Dept. of Botany, pp. 92.

Simidchiev T. (1970) Prinosz kom proucsvane biologijata na cöftezsa i nektarootdeljaneto na krusata (Pyrus communis L.). (Studies on floral biology and nectar secretion of pear (Pyrus communis L.)). Naucsni Tradove na Viszs Szelkosztopanszi Insztitut "V. Kolarov" - Plovidiv, Plovdiv 19: 73-87.

Szabó-Mühlenkampf E. (1994) Spur típusú almafajták nektáriumszerkezete és nektártermelése.
(Nectary structure and nectar secretion of spur type apple cultivars). Doct. dissertation. JPTE Dept. of Botany, pp. 159.

Szilva Á. (1969) Gyümölcstermesztésünk és a méhészet. (Fruit production and apiculture.) Méhészet 12: 63-66.

Terpó A. (1980) Virágbiológiai alapismeretek. (Basic floral biology) In: Nyéki J. (szerk.): Gyümölcsfajták virágzásbiológiája és termékenyülése. (Floral biology and fertilisation of fruit cultivars) Budapest, Mezőgazd. Kiadó. 8-9.

Walker A. K., Barnes D. K., Furgala B. (1974) Genetic and environmental effects on quantity and quality of alfalfa nectar. Crop. Sci. 14: 235238.

Witt T., Jürgens A., Geyer R., Gottsberger G. (1999) Nectar Dynamics and Sugar Composition in Flowers of Silene and Saponaria Species (Caryophyllaceae). Plant Biol. 1: 334-345.

Addresses of the authors: Á. Farkas (e-mail: gigi@ttk.pte.hu), Zs. Orosz-Kovács (e-mail: kozsu @ ttk.pte.hu), University of Pécs, Department of Botany, Ifjúság u. 6., H-7624 Pécs, Hungary. 